\title{
The Most Important Factor in the Development of Energy-Agro-Industrial Complex and Society (On the Example of Georgia)
}

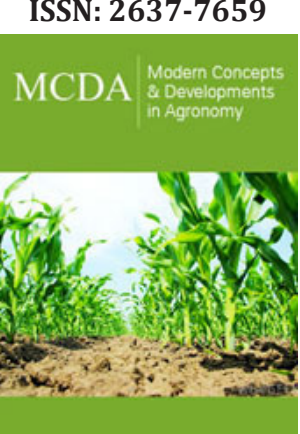

*Corresponding author: Demur Chomakhidze, PhD in Economic Science, Georgia

Submission: 眥 May 31, 2019

Published: 祭June 04, 2019

Volume 4 - Issue 3

How to cite this article: Saima A. Scenario of Chilli Production and Hindrances Faced by the Growers of Sindh Province of Pakistan. Mod Concep Dev Agrono.4(3). MCDA.000589.2019.

DOI: 10.31031/MCDA.2019.04.000589

Copyright@ Demur Chomakhidze, This article is distributed under the terms of the Creative Commons Attribution 4.0 International License, which permits unrestricted use and redistribution provided that the original author and source are credited.

\author{
Demur Chomakhidze* and Khatuna Chomakhidze
}

$\mathrm{PhD}$ in Economic Science, Georgia

\section{Opinion}

It is predicted that by mid of $21^{\text {st }}$ century as a result of the prodigal consumption of natural gas, oil and other energy resources, hydrocarbon energy resources will be fully exhausted. At the same time excessive and irrational consumption of energy creates severe environmental problems. This stipulates new approach to the development of fuel and energy complex. On the basis of experts' analysis on energy development on a global scale, moving from traditional non-renewable organic to renewable and inexhaustible resources consumption is essential. As a result, great majority of the countries develop their own energy policy and strategy on the basis of domestic energy resources separately or in close cooperation with the other countries; mainly targeting safe, reliable and effective satisfaction of the increasing energy demand. Taking into account the geopolitical state of Georgia, electricity and fuel supplies on the basis of domestic energy resources together with import, and its integration to regional or world energy markets is one of key factors of independent, safe and rapid socialeconomic development of the country. The energy complex of Georgia includes all kinds of energy and raw materials consumption; it consists of prospecting, enriching, refining, storing, transporting and utilizing systems together with environment protection network.

The energy complex is one of the basic elements of the economy, playing leading role in social-economic development, scientific-technological progress, establishment of infrastructure and industrial output increase. Therefore, the level of energy production and consumption per capita is one of the key indexes of the development all over the world; and the provision of a stable energy supply is one of the most important factors in modern society. Experts' analysis on "biosphere-society-economy" show that energy consumption is a considerably more reliable parameter for economic development than GDP of the country in modern world. The basic aims of Georgian energy strategy differ considerably from the countries having domestic organic fuel resources. It is acknowledged that during the long historical period up to the end of $20^{\text {th }}$ century, Georgia had no sufficient internal primary energy resources and thus had to import approximately $85 \%$ of the primary fuel. However, Georgia has internally available most of the energy resources used all over the world. These are: coal, peat, oil, natural gas, geothermal waters; a high potential for wind, solar, biomass and geothermal energies. Georgia is rich in hydro energy resources; technical potential makes up 80billion kWh per year (economically exploitable hydro resources make up 40billion kWh per year), while currently only $9 \%$ is utilized. The geographical state and transit potential of Georgia is of a particular significance. The above mentioned creates the strong base for economic development of Georgia and forms the powerful key factors for local and regional energy perspectives for Georgia. Together with the significant natural resources, Georgia has big human intellectual and scientific-technical resources. One of the most severe problem, effecting the energy strategy of Georgia is energy intensity declining in national economy. Together with the difficulties typical for transit economy Georgian energy strategy must consider the world and regional economic development rates.

At present the balance between production and consumption of energy resources per capita is not the case -it makes up to 0.6 tons of equivalent fuel (toe), whereas the similar world index is equal to 1.5tons and in the developed countries more than 3 tons. Improvement in power production requires higher increase rate. World electricity production increase rate 
forecast for $2001-2020$ predicts $2.6 \%$, though for the economically developed counties up to $1.7 \%$. The acceptable electricity production increase rate for Georgia must reach approximately 3\%. Today the economic trends show prospects of energy demand increase. So, it is necessary to solve the problems, in a global scale, under strict market conditions. The satisfaction of modern demands is possible by means of the qualitatively renewed energy complex from the viewpoint of modern marketing. Constant provision of energy products to the Georgian economy and population is possible by means of long-term, feasible energy strategy, equally reasonable for the social and the state governmental institutions.

This strategy includes:

a) energy policy (a tool for carrying out energy strategy),

b) energy safety and environmental protection,

c) strategic programs focused on each particular field development.

Georgian energy strategy up to 2020 is the document giving concrete expression to: the aims and targets of the Georgian longterm energy policy; energy complex role during the forecasted period under the circumstances created into the country or initiated out of it, like Georgian economic trends, energy market globalization, political developments, macroeconomic and scientific-technological prospects.

\section{Main target of energy strategy is}

a) To define the ways to achieve qualitatively new state of the energy complex,

b) To increase potential of capacities on regional market, and competition (benefiting from own infrastructure) based upon defined priorities of energy complex development and final forecast data for current potential,

c) To formulate the State Energy Policy implementing measures.

The energy strategy conceptual framework includes

a) Energy provision to the state economy and resident consumers in reasonable, energy-conservative and incentive price regime,

b) Reduction of lack of energy supply and related risks,

c) Lowering energy rate consumption at industrial and residential level,

d) Rational consumption of energy,

e) Consumption of energy saving technologies and equipment, f) Lowering production, refining and transporting charges,

g) Improving financial situation,

h) Energy efficiency growth,

i) Minimization of energy production restricted by environmental rules using new technologies for prospecting, refining and transportation.

Basic way for implementing energy strategy programme is the formation of modern energy market, based on commercial economic relations. Where the State limits its operational functions and strengthens its own role as a regulator in marketing trends, natural monopoly, tariff regulation and tariff gradual liberalization issues. The state regulation means are:

a) antimonopoly regulation of tariff, taxation, custom clearances, and institutional reforms of the energy complex,

b) increase state-enterprise management efficiency,

c) adopting technical norms and standards stimulating energy development management,

d) support and encourage economic initiatives related with the investments, innovations and energy saving.

Energy strategy program anticipates

a) political and economic stability of the country,

b) expedient national economy,

c) adopting less energy-intensive technologies,

d) relevant industrial and social factors,

e) active state support for such long-range programs.

The energy policy as integral part of this strategy is based on

a) permanent and successive process of reforms,

b) application of technical innovations,

c) investment stimulating measures.

As for improving investment climate, special attention has to be paid to the state attitude towards private investments in rehabilitation and construction, meaning encouraging investor with acceptable taxation and regulatory policy. High rates of new energy capacities, especially in hydro energy is possible if a favourable investment environment is formed. Attention must be paid to the abovementioned problems in the state management organizations taking into account that the advanced rates of energy development is of unique importance for the economy rise as a whole. especially for energy-agro-industrial complex. 